\title{
Sediment mineralization, nutrient fluxes, denitrification and dissimilatory nitrate reduction to ammonium in an estuarine fjord with sea cage trout farms
}

\author{
Peter Bondo Christensen ${ }^{1, *}$, Søren Rysgaard ${ }^{1}$, Niels Peter Sloth $^{1}$, Tage Dalsgaard ${ }^{1}$, \\ Steen Schwærter ${ }^{2}$
}

${ }^{1}$ National Environmental Research Institute, Department of Lake and Estuarine Ecology, Vejlsøvej 25, 8600 Silkeborg, Denmark ${ }^{2}$ Vejle County, Damhaven 12, 7100 Vejle, Denmark

\begin{abstract}
Sediment oxygen consumption, nutrient fluxes across the sediment-water interface, denitrification, and dissimilatory nitrate reduction to ammonium (DNRA) were measured in sediment below the cages of a rainbow trout farm in the estuary of Horsens Fjord, Denmark, and compared to that in the sediment at reference stations elsewhere in the fjord. Denitrification and DNRA were measured by the isotope pairing technique and a ${ }^{15} \mathrm{~N}$ technique, respectively. The measurements are the first published data of in situ activities in sediment below marine fish farms. Oxygen consumption by the sediment and effluxes of $\mathrm{NH}_{4}{ }^{+}$and $\mathrm{PO}_{4}{ }^{3-}$ were markedly stimulated by organic matter loading from the overlying fish cages. Denitrification of nitrate from the water column $\left(D_{w}\right)$ was only of significance during autumn and winter when runoff from land resulted in high water column nitrate concentrations. In contrast, coupled nitrification-denitrification $\left(D_{n}\right)$ occurred in the sediment throughout the summer, with the rates in the sediment below the fish cages surprisingly being of the same magnitude as those at the reference stations. Competition for inorganic nitrogen from benthic microalgae probably inhibited the activity of both nitrifiers and denitrifiers at the reference stations, while a mat of Beggiatoa spp. on the sediment surface below the fish cages in late summer indicated the presence of sulfide in the uppermost layers of the sediment, which almost ceased $D_{n}$. While DNRA was absent in sediment unaffected by the trout farms, it was of quantitative importance in the reduced sediment below the fish cages, DNRA activity being up to 7 -fold greater than denitrification activity. The ecological consequence of this shift in the relative importance of the processes in response to organic matter loading was a reduced nitrogen removal by denitrification and an increased efflux of $\mathrm{NH}_{4}{ }^{+}$to the water column, resulting in stimulation of pelagic primary production and increased nitrogen retention by the ecosystem. The excess nitrogen input to the fjord from the trout farms corresponded to approximately $12 \%$ of the total nitrogen load from land during the summer months. Only $0.1 \%$ of this additional nitrogen input was removed by denitrification in the underlying sediments during the fish production season. In general, shallow estuarine ecosystems hosting fish farms may therefore face increasing eutrophication problems due to the direct supply of nutrients in the fish food and to shifts in the dominant microbial processes in the sediment below the fish cages.
\end{abstract}

KEY WORDS: Aquaculture - Flux rates - Denitrification - DNRA - Isotope pairing technique - Benthic microalgae

\section{INTRODUCTION}

World marine aquaculture production of fish and shellfish increased from 3.0 million $t$ in 1986 to 7.2 million $t$ in 1995 (FAO Fisheries Department 1997). It is

•E-mail: pbc@dmu.dk consequently important to elucidate the local environmental impact of this production. In Denmark, marine aquaculture production is almost exclusively based on sea cage farming of rainbow trout Oncorhynchus mykiss in estuarine fjords, with production amounting to $8800 \mathrm{t}$ in 1996 (Danish Environmental Protection Agency 1997, Hassager \& Prince1997). 
The environmental influence of residual fish food and excreta from fish cages is of particular interest in small estuaries with a long water residence time. More than $70 \%$ of the total nitrogen and phosphorus content of the fish food is usually lost to the aquatic environment (Hall et al. 1992). In shallow estuaries, excess food and fecal pellets settle on the sea bed close to the fish cages where the material is often visible as thick layers of residual organic matter on the sediment surface. The sediment below the fish cages is thus dark, often smelling of sulfide, and may be covered with white sulfur bacteria (e.g. Kaspar et al. 1988, Hall et al. 1992, Karakassis et al. 1998). The organic material is rapidly mineralized, thereby releasing nutrients to the overlying water column. Input of waste products from fish farms thus stimulates total sediment metabolism (Hall et al. 1992) and, in particular, oxygen respiration and sulfate reduction (Holmer \& Kristensen 1994).

Bacterial nitrification and denitrification under such reduced conditions are of particular interest since they are involved in removal of the nitrogen load from the fish farms. In order to evaluate the environmental impact of aquaculture production it is necessary to determine how much of the nitrogen load can be removed from the environment by denitrification, whether denitrification is stimulated or inhibited by excess organic matter loading, and whether the sediment can recover during the winter break in fish production, when strong winds can cause waves, high water currents and resuspension events.

Kaspar et al. (1988) reported that nitrification and denitrification were not measurable in the immediate vicinity of fish cages in New Zealand coastal waters. Denitrification measured as potential activity in slurries was virtually absent in the sediment below the fish cages, where the dominant nitrate reducing process was dissimilatory nitrate reduction to ammonium (DNRA). Similarly, Gilbert et al. (1997) found high rates of DNRA in sediment exposed to high deposition from a mussel farm in a Mediterranean lagoon. The sediment was clearly visually affected by the deposits and was anoxic during part of the season. Finally, Hall et al. (1992) found very low rates of denitrification in sediments subjected to waste deposition from fish farms and presumed that DNRA was taking place. The findings are in agreement with the general consensus that DNRA dominates in carbon-rich environments with low availability of electron acceptors (Nishio et al. 1983, Tiedje 1987).

In all of the above-mentioned studies denitrification was measured with an acetylene inhibition technique, while DNRA was measured in slurries with a ${ }^{15} \mathrm{~N}$ technique. The acetylene inhibition technique is subject to potential problems, however, primarily because nitrification, and hence coupled denitrification, is inhibi- ted by acetylene (Bédard \& Knowles 1989) and because inhibition of denitrification by acetylene can sometimes be incomplete, particularly in the presence of sulfide (Sørensen et al. 1987, Christensen et al. 1989). Moreover, the use of slurries is doubtful since naturally occurring physical, chemical and biological gradients are distorted, which may greatly influence the measured processes and yield rates far from in situ activities.

In the present study of the impact of fish farming in Horsens Fjord we measured oxygen consumption and nutrient fluxes under in situ conditions in undisturbed sediment cores. In addition, we applied the isotope pairing technique and a modified ${ }^{15} \mathrm{~N}$ technique to the same sediment cores to obtain estimates of denitrification and DNRA in undisturbed cores under in situ conditions. Four Iocations in Horsens Fjord were sampled 6 times during the period April to November, which is the production period for the rainbow trout farms. Two stations below 2 of the fish cages represented sediment loaded with high amounts of organic matter (cage stations) while 2 stations far from the fish farms represented the unaffected sediment (reference stations).

\section{METHODS}

Study site. Horsens Fjord is a shallow estuarine fjord with a surface area of $77.5 \mathrm{~km}^{2}$ located in the eastern part of Jutland, Denmark (Fig. 1). The average depth is $2.9 \mathrm{~m}$ and the maximum depth is $22 \mathrm{~m}$. The fjord opens into the Kattegat and the salinity varies from $16 \%$ in the western part to $25 \%$ in the eastern part (average

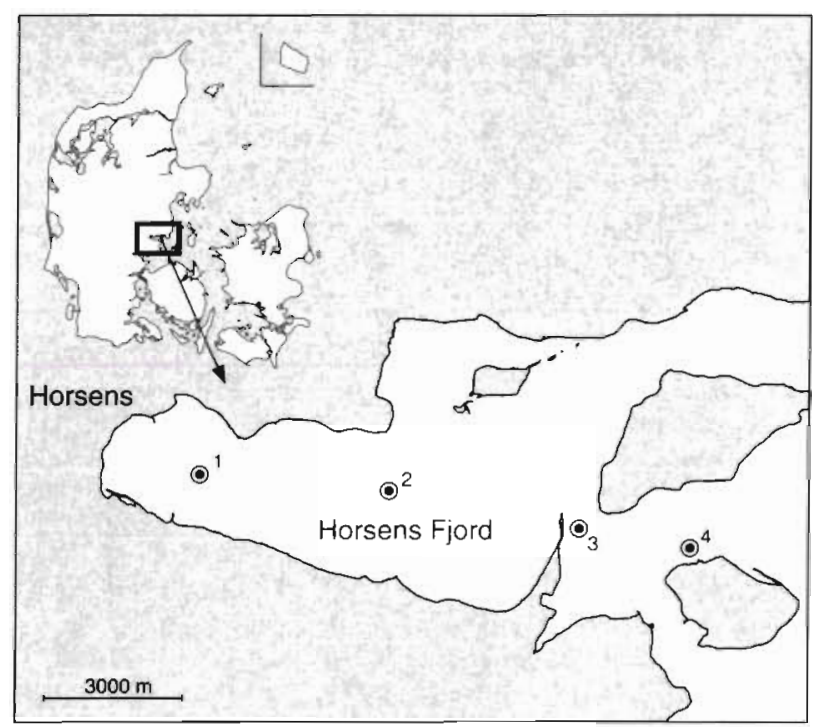

Fig. 1. Sampling sites in Horsens Fjord situated on the east coast of Jutland, Denmark 
1989 to 1995; Vejle County 1996). Water temperature varies from approximately $3^{\circ} \mathrm{C}$ in January to approximately $18^{\circ} \mathrm{C}$ in August (average 1989 to 1995; Vejle County 1996). Runoff from the catchment area $\left(449 \mathrm{~km}^{2}\right)$ amounted to approximately 100 million $\mathrm{m}^{3}$ in 1996, with the freshwater residence time during summer and winter being 18 and $13 \mathrm{~d}$, respectively. Tidal action is low, the inter-tidal range generally being less than $0.5 \mathrm{~m}$. The wind is generally moderate in summer months, increasing in autumn and winter. This was also the case during the study year, 1996. The fjord was ice covered from December 1995 until early April 1996, which is unusual.

Precipitation was extremely low during 1996, and nitrogen and phosphorus loading from the land was consequently significantly lower than during years with normal precipitation. Nitrogen and phosphorus input to the fjord from the catchment area in 1996 thus only amounted to 1022 and $22 \mathrm{t}$, respectively, which is approximately $50 \%$ of mean $\mathrm{N}$ and $\mathrm{P}$ loading during the period 1989 to 1995 (Vejle County 1996). During the summer period (1 June to 30 September), total loading of the fjord from the land amounted to $146 \mathrm{t} \mathrm{N}$ and $4.8 \mathrm{t} \mathrm{P}$. Estimates of possible nutrient loading from the adjacent Kattegat are not available, and input of nutrients from this source is consequently not included in the following calculations.

Primary production in the fjord is usually limited by nitrogen availability in the summer months (June, July and August), when the DIN concentration is less than $1 \mu \mathrm{M}$ (data for the years 1989 to 1996; Vejle County 1997). Phosphorus availability may limit production in April-May, when the concentration may be less than $0.1 \mu \mathrm{M}$. Productivity and chlorophyll concentrations are generally high in Horsens Fjord (up to $350 \mathrm{~g} \mathrm{C} \mathrm{m}^{-2}$ $\mathrm{yr}^{-1}$, and $19 \mu \mathrm{g}$ chlorophyll $\mathrm{l}^{-1}$; data for the years 1985 to 1996 , Vejle County 1997). The bottom water in some areas is periodically subject to oxygen depletion, and hence sensitive to excessive nutrient loading.

Aquaculture. Trout Oncorhynchus mykiss are farmed at 4 locations in the fjord where high currents and wind exposure are expected to remove dissolved and particulate residues during the winter break in production (Vejle County 1997). At each location, 12 to 24 cages are established during the growth season, covering a total area of approximately $18700 \mathrm{~m}^{2}$. Annual trout production in Horsens Fjord has increased from $388 \mathrm{t}$ in 1988 to $686 \mathrm{t}$ in 1996 . Trout production is not undertaken during the winter period.

In 1996, the fish cages were established in April, and smolt weighing 700 to $900 \mathrm{~g}$ was added. The fish were fattened during the summer and slaughtered in November at a weight of 3 to $5 \mathrm{~kg}$. Total production amounted to $686 \mathrm{t}$ wet weight and total feed consumption to $759 \mathrm{t}$ dry weight. Total release of $\mathrm{N}$ and $\mathrm{P}$ from the fish farms in 1996 including excess fish feed and excreta was calculated to be 25.7 and $2.9 \mathrm{t}$, respectively (Vejle County 1996). The fish are exclusively fed on dry feed with a low $\mathrm{N}$ and $\mathrm{P}$ content $(38 \%$ protein and $0.8 \% \mathrm{P}$ ) to meet environmental requirements imposed by the authorities. As approximately $16 \%$ of the protein in the fish feed is nitrogen, $56 \%$ of the nitrogen added with the food each year is thus lost to the fjord.

The $25.7 \mathrm{t} \mathrm{N}$ and $2.9 \mathrm{t}$ P released from the fish farms corresponded to 2.5 and $13 \%$, respectively, of total annual $N$ and $P$ loading of the fjord from land-based sources in 1996 (1022 t N and $22 \mathrm{t}$ P). During the summer months (1 June to 30 September), $N$ and P loss from the fish farms amounted to 18 and $2 \mathrm{t}$, respectively, corresponding to 12 and $42 \%$ of total $\mathrm{N}$ and $\mathrm{P}$ loading from land during summer 1996 (146 t $\mathrm{N}$ and $4.8 \mathrm{tP}$ ).

Sampling stations. The reference stations (Stns 1 and 2) were situated in the central part of the estuary, far from the fish farms (Fig. 1), while the cage stations (Stns 3 and 4) were located directly below 2 of the fish cages. The water depth at Stns 1,2,3, and 4 was 4, 5, 9 , and $3 \mathrm{~m}$, respectively. The sediment at all stations was sandy and very similar with respect to porosity (approximately 0.8 ) and organic carbon content (approximately $8 \%$ ).

Sampling. Sediment cores were sampled on 6 dates during 1996 to follow changes during the aquaculture production period. Initial sampling in April was performed before fish were added to the cages. On each date, 8 sediment cores were collected at each of the 4 stations. Sampling was performed by scuba diving, collecting the sediment samples in $30 \mathrm{~cm}$ long Plexiglas tubes (i.d. $52 \mathrm{~mm}$ ). At Stns 3 and 4 the sediment cores were sampled below the center of the fish cage. The cores were closed with rubber stoppers and transferred to the laboratory within $3 \mathrm{~h}$.

In the laboratory, sediment height was adjusted to approximately $7 \mathrm{~cm}$, giving a water height of approximately $20 \mathrm{~cm}$. The cores were placed in a thermostatically regulated reservoir kept at in situ temperature. The cores from each station were placed in separated reservoirs containing $10 \mathrm{l}$ water from the sampling station. Teflon-coated magnets $(0.5 \times 3 \mathrm{~cm})$ were placed in the water column $5 \mathrm{~cm}$ above the sediment surface and driven by an external rotating magnet $(60 \mathrm{rpm})$ to ensure appropriate stirring of the water column. Since the bottom water oxygen concentration was close to atmospheric saturation on all sampling dates, the cores were always incubated at air-saturated conditions. To ensure steady-state concentration profiles, the cores were left uncapped and in contact with the reservoir water for $16 \mathrm{~h}$ before incubation was initiated on the following day.

In addition to the seasonal sampling, sediment cores were sampled in September along a $110 \mathrm{~m}$ transect 
radiating from the center of one of the fish cages. Sampling differed slightly from that described above. Fifteen undisturbed sediment cores were collected in $18 \mathrm{~cm}$ glass cores (sediment height: approximately $10 \mathrm{~cm}$, i.d. $52 \mathrm{~mm}$ ) by scuba diving. Triplicate cores were collected immediately below the center of the cage and at distance of 2,10,20, and $100 \mathrm{~m}$ from the perimeter of the cage. The sediment cores from each locality were submerged at in situ temperature in a thermostatically regulated reservoir containing 151 water from the sampling spot. Stirring was provided by rotating Teflon-coated magnets $(0.5 \times 3 \mathrm{~cm}, 60 \mathrm{rpm})$ mounted $5 \mathrm{~cm}$ above the sediment surface, and the $\mathrm{O}_{2}$ concentration was held at atmospheric saturation.

Experimental design. Fluxes of $\mathrm{O}_{2}, \mathrm{NO}_{3}{ }^{-}+\mathrm{NO}_{2}{ }^{-}$, $\mathrm{NH}_{4}{ }^{+}$, and $\mathrm{PO}_{4}{ }^{3-}$ were measured on each sampling date. Water samples were first taken from the reservoir in which the sediment cores were being preincubated. The cores were then capped and incubated for 2 to $8 \mathrm{~h}$, whereafter water samples were collected from each core. Four of the cores from each station were lightincubated by using a transparent cap that provided a light intensity at the sediment surface similar to that under in situ conditions. The remaining 4 cores from each station were incubated in total darkness. The duration of incubation was adjusted during the study so as to keep the change in oxygen concentration during the incubation period below $20 \%$. Parallel incubations with Plexiglas tubes containing in situ water samples were used to correct for water column activity. Water samples for $\mathrm{O}_{2}$ concentrations were analyzed within $24 \mathrm{~h}_{\text {i }}$ samples for nutrients were immediately frozen for later analysis.

After the flux measurements, the cores were left uncapped for $16 \mathrm{~h}$ to allow equilibrium to be reached with the reservoir water before denitrification activity was measured in the same cores using the ${ }^{15} \mathrm{~N}$ isotope pairing technique (Nielsen 1992). ${ }^{15} \mathrm{~N}$-labelled $\mathrm{NO}_{3}{ }^{-}$ was added to the reservoir to a final concentration of 20 to $60 \mu \mathrm{M}$ (depending on the season). The water phase and sediment porewater in the uncapped cores were allowed to equilibrate for 15 to $30 \mathrm{~min}$ before the cores were closed and incubated for the same period of time as in the flux measurements. At the end of the incubation period, water was sampled from the water column of each core. To stop all bacterial activity, $1 \mathrm{ml}$ of $\mathrm{ZnCl}_{2}$ solution. $(50 \% \mathrm{w} / \mathrm{w})$ was then added to the sediment surface and the entire core gently stirred before sediment porewater was sampled as a subsample of the slurry. The samples for isotopic analysis of $\mathrm{N}_{2}$ were preserved in gas-tight containers (Exetainers, Labco, High Wycombe, UK) with $\mathrm{ZnCl}_{2}$ ( $2 \%$ volume of a $50 \% \mathrm{w} / \mathrm{w}$ solution) until mass spectrometric analysis.

In the September transect experiment, the water in the reservoir was enriched with ${ }^{15} \mathrm{~N}$-labelled $\mathrm{NO}_{3}{ }^{-}$to a final concentration of $13 \mu \mathrm{M}^{15} \mathrm{NO}_{3}{ }^{-}$on the first day of the experiment. To obtain measurements of DNRA, the experiment was conducted over a $5 \mathrm{~d}$ period, which ensured equilibrium between dissolved ${ }^{15} \mathrm{NH}_{4}{ }^{+}$in the pore water and ${ }^{15} \mathrm{NH}_{4}$ adsorbed to particles. Each day, 51 of the reservoir water were replaced with an equal volume of freshly ${ }^{15} \mathrm{NO}_{3}{ }^{-}$enriched bottom water from the locality in order to maintain a constant $\mathrm{NO}_{3}{ }^{-} \mathrm{con}$ centration in the core water column. All incubations were performed in the dark. On each day during the experiment, the cores were closed for approximately $40 \mathrm{~min}$ with rubber stoppers leaving a water column of $6 \mathrm{~cm}$ above the sediment. The resultant decrease in $\mathrm{O}_{2}$ concentration during this incubation period was approximately $20 \%$ of the initial concentration. Initial water samples were collected from the reservoir, and final samples were taken from the water column of each core. The water samples were analyzed for $\mathrm{O}_{2}$, $\mathrm{NO}_{2}{ }^{-}, \mathrm{NO}_{3}{ }^{-}, \mathrm{NH}_{4}{ }^{+}$, and the isotopic composition of $\mathrm{NO}_{3}{ }^{-}, \mathrm{NH}_{4}{ }^{+}$, and $\mathrm{N}_{2}$ was determined. Sample preservation was undertaken as described above.

Sediment water fluxes, denitrification and DNRA were calculated for each of the 5 days. As the rates only differed slightly from Day 4 to Day 5 , the rates on Day 5 were assumed to represent the steady state for each of the processes.

Nutrient analyses. Oxygen concentration was determined by Winkler titration (Grasshoff et al. 1983). $\mathrm{NO}_{2}{ }^{-}$ and $\mathrm{NO}_{3}{ }^{-}$were analyzed by standard cadmium reduction using a flow injection analyzer (Alpchem FS3000, Perstorp Analytical Environmental Inc., Oregon, USA). Ammonium was analyzed by the salicylate-hypochlorite method of Bower \& Holm-Hansen (1980). Phosphate was determined colorimetrically as described in Grasshoff et al. (1983).

Isotope analysis. $\mathrm{N}_{2}$ was extracted from the water in the glass vials by replacing $4 \mathrm{ml}$ of the sample with helium and shaking vigorously for $10 \mathrm{~min}$. The gas phase was then analyzed for the concentration and isotopic distribution of ${ }^{28} \mathrm{~N}_{2},{ }^{29} \mathrm{~N}_{2}$ and ${ }^{30} \mathrm{~N}_{2}$ on a triple collector mass spectrometer (RoboPrep-G+ in line with Tracermass, Europa Scientific, UK). The ${ }^{15} \mathrm{~N}$ labelling of the $\mathrm{NO}_{3}{ }^{-}$in the overlying water was determined by bacterial conversion of $\mathrm{NO}_{3}^{-}$to $\mathrm{N}_{2}$ and analysis of its isotopic composition by mass spectrometry as described by Risgaard-Petersen et al. (1993). Isotopic composition of ${ }^{15} \mathrm{NH}_{4}{ }^{+}$was determined following microdiffusion and hypobromite oxidation of $\mathrm{NH}_{4}{ }^{+}$to $\mathrm{N}_{2}$ (Risgaard-Petersen et al. 1995).

Calculations. Sediment water nutrient and oxygen fluxes were calculated from the incubation time, the measured height of the water column in each core and the concentration changes during incubation, with correction being made for water column activity. The denitrification rate of added ${ }^{15} \mathrm{NO}_{3}^{-}\left(D_{15}\right)$ and in situ ${ }^{14} \mathrm{NO}_{3}{ }^{-}$ 
$\left(\mathrm{D}_{14}\right)$ was calculated from the measured production of ${ }^{14} \mathrm{~N}^{15} \mathrm{~N}$ and ${ }^{15} \mathrm{~N}^{15} \mathrm{~N}$ (Nielsen 1992). In situ denitrification rate was divided into denitrification based on $\mathrm{NO}_{3}{ }^{-}$ from the water column $\left(\mathrm{D}_{\mathrm{w}}\right)$ and denitrification based on $\mathrm{NO}_{3}{ }^{-}$produced in the sediment by nitrification $\left(D_{n}\right)$. In situ rates of DNRA was calculated from the production rate of ${ }^{15} \mathrm{NH}_{4}{ }^{+}\left(\mathrm{p}^{15} \mathrm{NH}_{4}{ }^{+}\right)$during the incubation on Day 5 in the transect experiment. Assuming that DNRA takes place in the same layers as denitrification, the ${ }^{15} \mathrm{~N}$ labeling of $\mathrm{NO}_{3}^{-}$being reduced to ammonia equals the ${ }^{15} \mathrm{~N}$ labeling of $\mathrm{NO}_{3}{ }^{-}$being reduced to $\mathrm{N}_{2}$. The in situ rate of DNRA of ${ }^{14} \mathrm{NO}_{3}{ }^{-}$can therefore be calculated as:

$$
\text { In situ DNRA }=\mathrm{p}^{15} \mathrm{NH}_{4}{ }^{+} \times\left(\mathrm{D}_{14} / \mathrm{D}_{15}\right)
$$

Further details are given in Risgaard-Petersen \& Rysgaard (1995) and Rysgaard et al. (1995).

Diurnal rates of sediment water fluxes and denitrification were calculated by multiplying the rates obtained in light and dark incubations by day and night length, respectively, for the sampling date in question.

Annual rates of denitrification for Horsens Fjord as a whole were calculated by weighting the measured rates at the reference and cage stations by the area they represent, i.e. 77.48 and $0.02 \mathrm{~km}^{2}$, respectively. Denitrification rates were integrated over the whole year using the average rates at the reference stations in April and November 1996 as representative for the winter period, when measurements were not made and production at the fish farms had ceased.

\section{RESULTS}

\section{Seasonal variation}

While there was only minor variation in oxygen and nutrient fluxes during the period April to November at the 2 reference stations (Stns 1 and 2), aquaculture production markedly influenced benthic mineralization, and considerable seasonal variation was observed in the sediment fluxes below the fish cages (Figs. 2 to 5).

\section{Oxygen flux}

The $\mathrm{O}_{2}$ concentration in the bottom water was generally close to saturation at all 4 stations, indicating a well-mixed water column throughout the fjord.

In April, when the fish cages were still empty, oxygen consumption was similar at all 4 stations (Fig. 2). The sediment oxygen uptake at the reference stations (Stns 1 and 2) was moderate, with the highest activity (up to $46 \mathrm{mmol} \mathrm{m}^{-2} \mathrm{~d}^{-1}$ ) being measured in June to August. A brownish layer of benthic diatoms was present on the sediment surface on some sampling dates during summer. Oxygen production by the algae resulted in an oxygen efflux in the light (data not shown) resulting in net diurnal oxygen production at both reference stations on some sampling dates, the highest rate being recorded in July at Stn 2 .

Oxygen uptake at Stns 3 and 4 increased rapidly after the trout were added to the cages (Fig. 2). Peak activity of $278 \mathrm{mmol} \mathrm{m}^{-2} \mathrm{~d}^{-1}$ was recorded during midsummer when it was up to 6 -fold greater than at the reference stations. Benthic algae were absent below the fish cages and oxygen flux was the same in both the light and the dark. In contrast, a dense mat of Beggiatoa spp. covered the sediment surface below the cages during summer.

\section{Nutrient flux}

The water column ammonium concentration in the central part of Horsens Fjord was low throughout summer ( 1 to $2 \mu \mathrm{M}$ ), increasing to approximately $7 \mu \mathrm{M}$ in November (Fig. 3).

All measurements but one revealed net uptake of ammonium by the sediment at Stns 1 and 2. This is
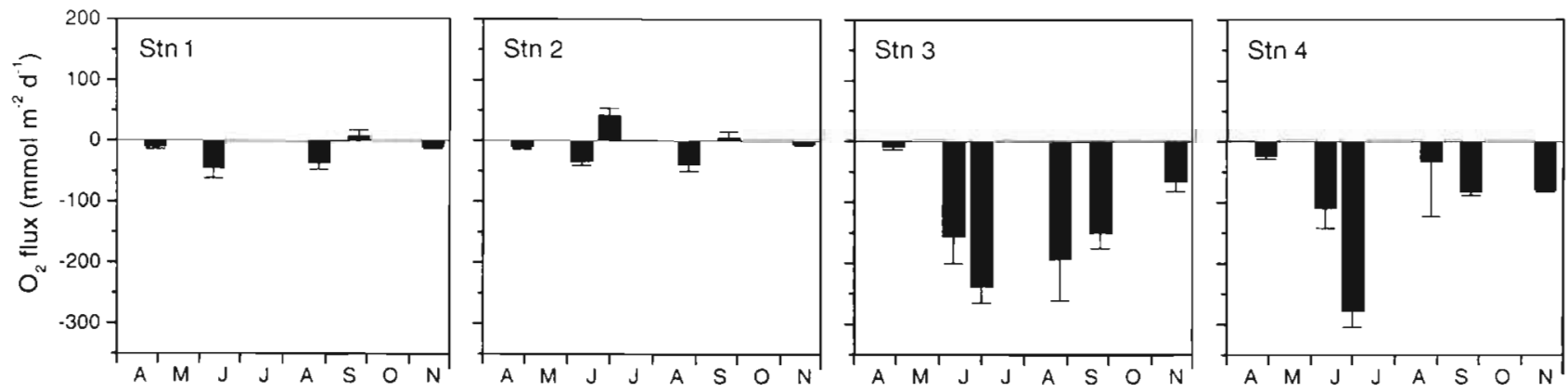

Fig. 2. Oxygen fluxes at the reference (Stns 1 and 2) and cage (Stns 3 and 4) stations during 1996. Positive fluxes represent efflux from the sediment, while negative fluxes represent uptake by the sediment. All data are means of dark and light incubated cores weighted by the day length on the sampling date $(\mathrm{n}=8 ; \mathrm{SE}$ indicated) 

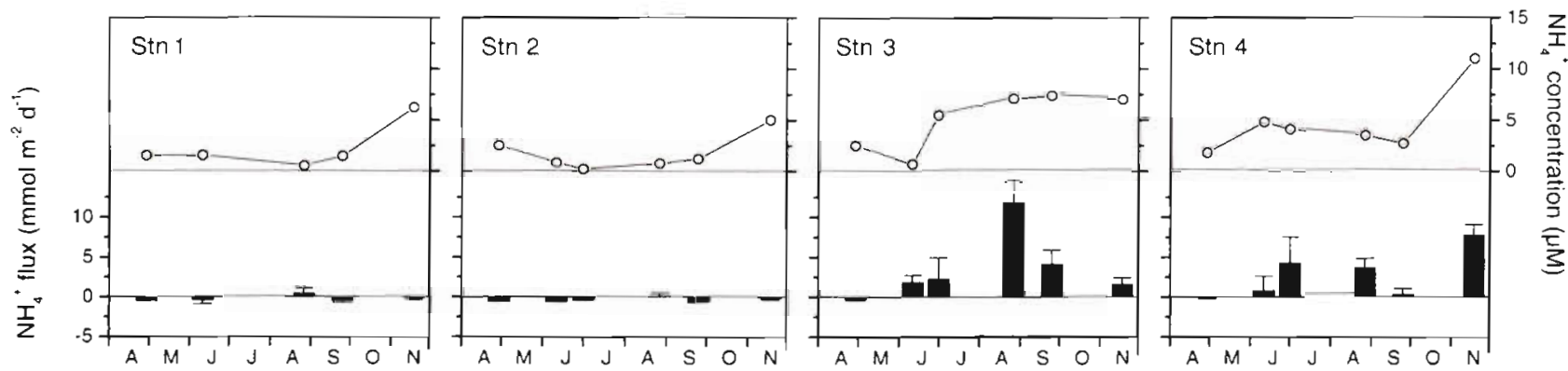

Fig. 3. Ammonium concentrations and fluxes at the reference (Stns 1 and 2) and cage (Stns 3 and 4) stations during 1996. Positive fluxes represent efflux from the sediment, while negative fluxes represent uptake by the sediment. All data are means of dark and light incubated cores weighted by the day length on the sampling date ( $\mathrm{n}=8$; SE indicated)
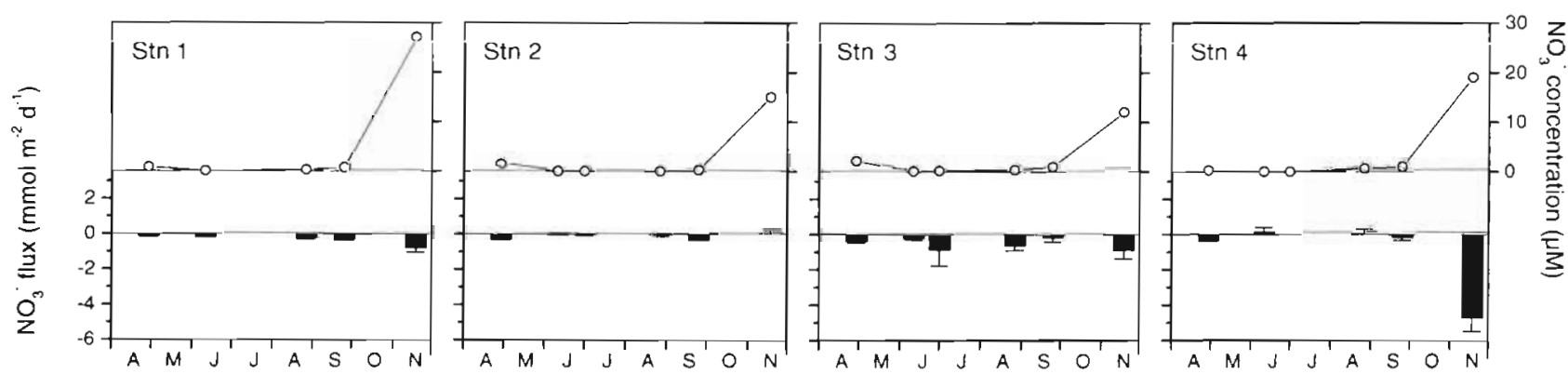

Fig. 4. Nitrate concentrations and fluxes at the reference (Stns 1 and 2) and cage (Stns 3 and 4) stations during 1996. Positive fluxes represent efflux from the sediment, while negative fluxes represent uptake by the sediment. All data are means of dark and light incubated cores weighted by the day length on the sampling date ( $n=8$; SE indicated)
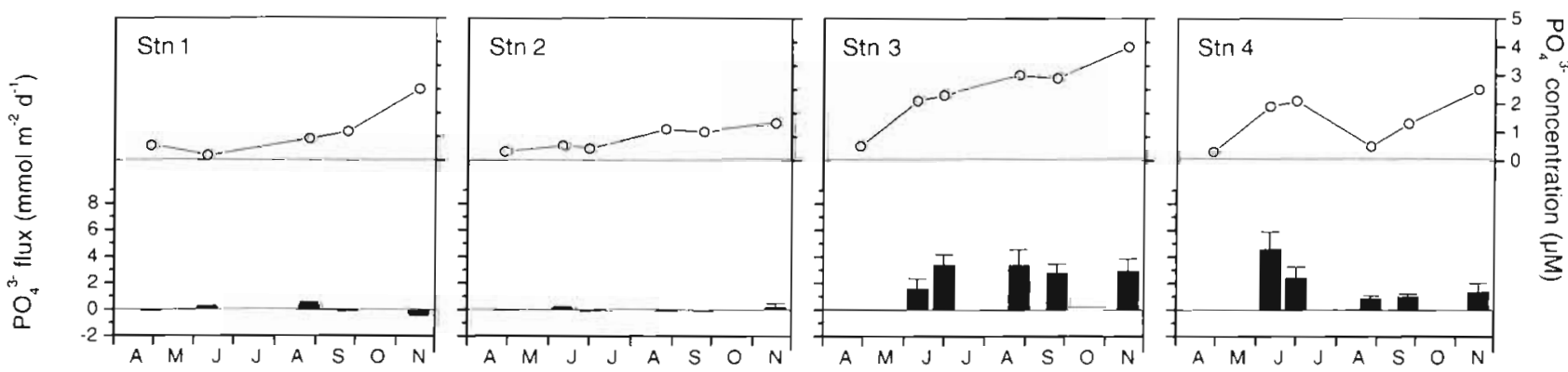

Fig. 5. Phosphate concentrations and fluxes at the reference (Stns 1 and 2) and cage (Stns 3 and 4) stations during 1996 . Positive fluxes represent efflux from the sediment, while negative fluxes represent uptake by the sediment. All data are means of dark and light incubated cores weighted by the day length on the sampling date $(\mathrm{n}=8$; SE indicated)

attributable to assimilation by benthic algae and uptake by nitrifying bacteria. Net efflux of ammonium was only observed at the reference stations in August, when oxygen uptake was highest (Fig. 2).

Net uptake of ammonium also took place at the cage stations in April prior to addition of the trout. After fish production started, there was a marked increase in ammonium efflux, with rates as high as $12 \mathrm{mmol} \mathrm{\textrm {m } ^ { - 2 }}$ $\mathrm{d}^{-1}$ being measured in the late summer months (Fig. 3 ). The efflux rates remained high until November, presumably reflecting the continuous degradation of organic matter within the sediment.
The high ammonium efflux rate at the fish cage stations was reflected in the bottom water, where the ammonium concentration increased to $5-7 \mu \mathrm{M}$ during summer, when the current is weak and the water residence time high. In addition to efflux from the sediment, direct excretion from the trout in the cages may also have contributed to the high water column ammonium concentration at the 2 cage stations.

Nitrate was virtually absent in the water column throughout the summer (Fig. 4), the concentration increasing to $12-27 \mu \mathrm{M}$ in November due to runoff from the land. The flux rate across the sediment-water inter- 


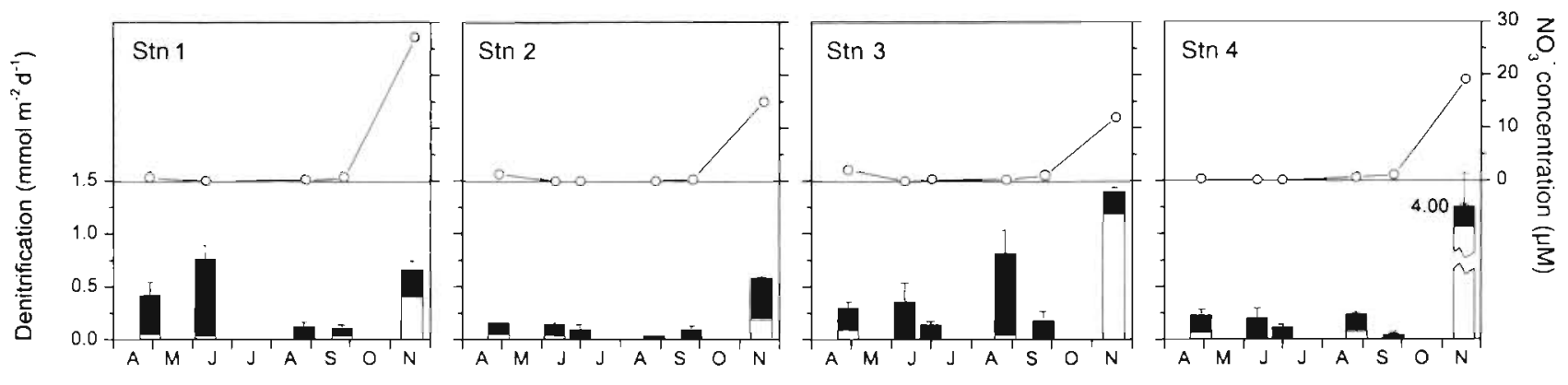

Fig. 6. Nitrate concentrations and denitrification based on $\mathrm{NO}_{3}{ }^{-}$from nitrification $\left(\mathrm{D}_{n}\right.$ ) (solid bars) and on water column $\mathrm{NO}_{3}{ }^{-}$ $\left(D_{w}\right.$ ) (open bars) at the reference (Stns 1 and 2) and cage (Stns 3 and 4) stations during 1996. Note the break in the denitrification bar for Stn 4 in November. All data are means of dark and light incubated cores weighted by the day length on the sampling date ( $\mathrm{n}=8$; SE indicated)

face was low and not markedly different at the reference and cage stations, there generally being a minor influx of $\mathrm{NO}_{3}^{-}$(0 to $1 \mathrm{mmol} \mathrm{m}{ }^{-2} \mathrm{~d}^{-1}$ ) except at Stn 4 in November, where the influx rate was high (Fig. 4).

The phosphate flux rate exhibited the same pattern as the ammonium flux rate (Fig. 5). At the reference stations the flux rate was low, and net uptake of phosphorus was occasionally observed. Trout production resulted in a high phosphate efflux rate below the fish cages during the summer and autumn months (up to $5 \mathrm{mmol} \mathrm{m}^{-2} \mathrm{~d}^{-1}$ ), as also reflected in the phosphate concentrations in the bottom water.

\section{Denitrification}

Denitrification based on $\mathrm{NO}_{3}{ }^{-}$from the water column, $\mathrm{D}_{\mathrm{n}}$, dominated at all stations during the summer (Fig , 6), when the bottom water concentration of $\mathrm{NO}_{3}{ }^{-}$was low. Thus, $D_{n}$ accounted for more than $90 \%$ of total denitrification activity at all stations during the summer period. Denitrification based on water column $\mathrm{NO}_{3}{ }^{-}, \mathrm{D}_{\mathrm{w}}$, was only of significance in November, when $\mathrm{NO}_{3}{ }^{-}$was present in high concentrations in the water column. The importance of the nitrate source in the water is reflected by the fact that the total denitrification rate was high in November, when $D_{w}$ accounted for the major part of the activity. $D_{w}$ was particularly important below the fish cages, where it accounted for 85 to $95 \%$ of total denitrification activity in November as compared with only 40 to $60 \%$ at the reference stations.

\section{Transect measurements}

When the transect measurements were undertaken in September, the sediment below the fish cage was covered by a thick homogeneous mat of Beggiatoa spp. The sediment $2 \mathrm{~m}$ from the cage perimeter was also covered by Beggiatoa spp., but the mat was much thinner. At a distance of $5 \mathrm{~m}$, no Beggiatoa spp. were observed. In contrast to the seasonal variation study, where a combination of light and dark measurements enabled calculation of diurnal rates, the transect measurements were only conducted as dark incubations.

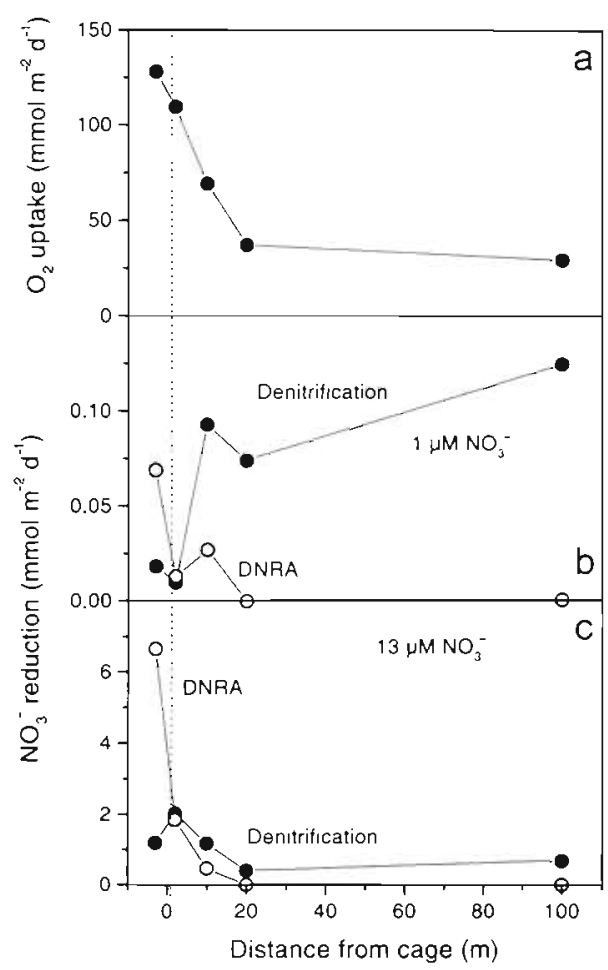

Fig. 7. Measurements of oxygen uptake, denitrification and dissimilatory nitrate reduction to ammonium (DNRA) along a transect from below the fish cage to a distance of $100 \mathrm{~m}$ from the perimeter of the cage ( $\mathrm{Stn} 4$, September 1996). (a) $\mathrm{O}_{2}$ uptake. (b) Rates of denitrification $\left(\mathrm{D}_{14}\right)$ and DNRA under in situ $\mathrm{NO}_{3}{ }^{-}$levels $\left(1 \mu \mathrm{M} \mathrm{NO}_{3}{ }^{-}\right)$. (c) Rates of denitrification $\left(\mathrm{D}_{14}+\mathrm{D}_{15}\right)$ and DNRA at enhanced $\mathrm{NO}_{3}^{-}$levels $\left(13 \mu \mathrm{M} \mathrm{NO}_{3}{ }^{-}\right)$. The vertical, dotted line represents the edge of the fish cage. (Data points are the mean of 3 cores) 
The data showed a clear local effect of trout production (Fig. 7). Thus $\mathrm{O}_{2}$ uptake was $128 \mathrm{mmol} \mathrm{m}^{-2} \mathrm{~d}^{-1}$ below the fish cage, decreasing to $29 \mathrm{mmol} \mathrm{m} \mathrm{m}^{-2} \mathrm{~d}^{-1}$ at a distance of $100 \mathrm{~m}$ from the cage (Fig. 7a), which is equivalent to the dark measurements at the reference stations. The in situ denitrification rate was lowest below the fish cages and increased outside the cages (Fig. 7b). The opposite pattern was seen with DNRA. Thus DNRA occurred in the sediment below the cage, but decreased to zero at a distance of $20 \mathrm{~m}$ from the perimeter. Higher $\mathrm{NO}_{3}{ }^{-}$concentration in the water column $(13 \mu \mathrm{M})$ caused a dramatic increase in the rate of DNRA below the cages. The denitrification rate also increased, especially under and near the cage (Fig. $7 \mathrm{C}$ ).

\section{DISCUSSION}

\section{Mineralization of organic matter}

Organic loading from the trout farms in Horsens Fjord was reflected in all sediment variable measurements made from the summer until the end of the year (Figs. 2 to 5). Thus, organic matter loading of the sediment during fish production resulted in extremely high oxygen consumption rates. The oxygen uptake rate of almost $300 \mathrm{mmol} \mathrm{m} \mathrm{m}^{-2} \mathrm{~d}^{-1}$ measured below the fish cages during summer is among the highest we have seen in any Danish sediment system (Rysgaard et al. 1995, Sloth et al. 1995, Risgaard-Petersen et al. 1998, Dalsgaard et al. 1999). The effects were rather local, however, as demonstrated by the transect measurements. Thus sediment oxygen uptake $100 \mathrm{~m}$ from the fish cages was comparable to that at the reference stations, and there were only minor differences between the values measured 20 and $100 \mathrm{~m}$ from the cages (Fig. 7). These findings are in accordance with Karakassis et al. (1998), who reported highly localized effects at distances up to $20-50 \mathrm{~m}$ from fish cages in the Mediterranean (water depth 16 to $20 \mathrm{~m}$ ). They noted, however, that more distant stations may also have been affected by loading from the fish farms, presumably due to resuspension of material under the cages in periods with strong wind-driven currents and direct transport of smaller particles.

Excess fish food and excreta were rapidly mineralized within the sediment, resulting in a significant efflux of nutrients. The high efflux of $\mathrm{NH}_{4}{ }^{+}$and $\mathrm{PO}_{4}{ }^{3-}$ was reflected in the bottom water at the cage stations, where elevated water column concentrations were measured during the summer (Figs. $3 \& 5$ ). Although the nutrient efflux from the sediment was of local importance, it may also comprise an important nutrient source for pelagic primary production in a large area of the fjord depending on the water currents and the water residence time. Loading from the land mainly occurs during winter, and the nutrients derived from the trout farms are therefore of particular importance during the summer months, when primary production is nitrogen-limited and nutrient runoff from the land is minimal. From June to September, when nitrogen limitation is most pronounced, the nutrient supply to the fjord in the form of excess food, excreta, etc. amounted to approximately $18 \mathrm{t} \mathrm{N}$ and $2 \mathrm{t} \mathrm{P}$. Although the fish farms only covered $0.02 \%$ of the total area of Horsens Fjord, direct $\mathrm{N}$ and $\mathrm{P}$ input from trout production comprised approximately 12 and $42 \%$, respectively, of total land-based loading of the entire fjord system during the summer months.

In April, all flux measurements were of the same magnitude at both the reference and cage stations, indicating that the sediment at the cage stations returned to normal conditions during the winter following the preceding trout production period. The organic matter load was presumably removed by the combined effect of continuous bacterial degradation within the sediment and transport out of the system by diffusion, resuspension and high water currents during winter. The excess organic matter is likely to be transported to deeper water, where degradation will continue until the residual fraction is finally buried. Such areas may experience prolonged and continuous influence of organic matter originating from other parts of the system. The permanent deposition areas in Horsens Fjord are located outside the mouth of the fjord. In 1996 , these areas were subject to severe oxygen depletion (Vejle County 1997). In contrast to the sediment immediately below the fish cages, the deposition areas may be influenced by fish production all year round. However, particle dynamics in the area have not been investigated.

\section{Denitrification}

Since the nitrate concentration in the water column of Horsens Fjord was low throughout the growth season, $D_{w}$ was correspondingly very low and of no quantitative significance during the summer months. $D_{w}$ was only of significance in early spring and late fall, when increased runoff from the surrounding land increased the nitrate concentration in the water column. In fall, when stimulation of $D_{w}$ was most pronounced, significantly higher activity was recorded below the fish cages than at the reference stations (Fig. 6). The high level of organic matter loading below the fish cages stimulated denitrification activity directly through additional input of electron donors. Moreover, it indirectly stimulated $\mathrm{D}_{w}$ as the diffusion distance for nitrate in the water column to the anoxic 
denitrification zone located immediately below the oxic surface layers of the sediment is reduced when oxygen consumption below the cages is enhanced (Christensen et al. 1989, Nielsen et al. 1990a,b).

Denitrification was detectable throughout the year below the fish farms in Horsens Fjord, thus indicating that denitrifying enzymes were present in the reduced sediment at all times. During the summer season, however, denitrification activity was almost exclusively related to nitrate produced by nitrification within the sediment $\left(D_{n}\right)$. The absence of denitrification activity below fish farms reported in previous studies has been attributed to both the absence of denitrifying enzymes, as demonstrated by potential assays, and to the inhibitory effect of sulfide on nitrification activity (e.g. Kaspar et al. 1988). The in situ denitrification rates hitherto reported were measured using the acetylene inhibition technique. As acetylene is known to also inhibit nitrification activity (Bédard \& Knowles 1989), denitrification rates obtained using the acetylene inhibition technique do not include coupled nitrification-denitrification activity. If $D_{n}$ was excluded from our data, total denitrification activity would also be very low or absent in these sediments. We therefore believe that the discrepancy between the present and published findings is due to the use of different methods and consider that the present study demonstrates that the isotope pairing technique is useful for measuring in situ denitrification under reduced conditions, where the acetylene inhibition technique may fail to detect in situ activity. To our knowledge, the presented data are thus the first real in situ measurements of denitrification in the sediment below aquaculture farms.

Surprisingly, $D_{\mathrm{n}}$ activity was as high or even higher below the fish cages than at the reference stations (Fig. 6). It might be expected that nitrification activity and hence coupled denitrification would be higher at the reference stations, where oxygen conditions in the surface layers were significantly better. However, benthic microalgae may compete with nitrifiers and denitrifiers for the available ammonium and nitrate, respectively (Rysgaard et al. 1995). In a comprehensive study including a number of Danish estuarine fjords, mats of benthic microalgae were found to inhibit denitrification activity almost completely when the concentration of inorganic nitrogen in the overlying water column was less than $5 \mu \mathrm{M}$ (Nielsen et al. 1994, Dalsgaard et al. 1999).

Coupled denitrification activity was only decreased below the fish farms in September, when the sediment was most reduced and the surface covered by white mats of Beggiatoa spp., in particular at Stn 4 (Fig. 6). When the transect measurements were made under these conditions, denitrification activity at the in situ nitrate concentration was severely inhibited below the fish farms as compared to that at a distance of only $20 \mathrm{~m}$ from the cages (Fig. 7b). Thus denitrification activity below the fish farms was found to be as low as $0.02 \mathrm{mmol} \mathrm{N} \mathrm{m}^{-2} \mathrm{~d}^{-1}$. In this situation with a nitrate concentration of less than $1 \mu \mathrm{M}$ in the overlying water, more than $99 \%$ of the total denitrifying activity was due to $D_{n}$ and it seems likely that the reduced activity below the cages at this time of the year was due to inhibition of nitrification by sulfide in the sediment (Joye \& Hollibaugh 1995)

\section{Nitrate reduction to ammonium}

In contrast, DNRA was highest immediately below the fish cages, being approximately 3 -fold greater than denitrification activity at in situ nitrate concentration (Fig. $7 \mathrm{~b}$ ) but absent only $20 \mathrm{~m}$ from the fish cages when measured in September. This confirms the general consensus that DNRA is stimulated in extremely carbon-rich environments (Tiedje 1987) but does not normally play an important quantitative role in estuarine sediments, as discussed by Binnerup et al. (1992) and Rysgaard et al. (1993).

DNRA can be performed by strictly anaerobic bacteria, i.e. sulfate-reducing bacteria when nitrate is available (e.g. Tiedje 1987, Dalsgaard \& Bak 1994), and the bacteria may be located close to the sediment surface under very reduced conditions. An elevated nitrate concentration in the water column $(13 \mu \mathrm{M})$ demonstrated a high potential for both DNRA and denitrification as both processes were greatly stimulated (up to 110-fold; Fig. 7b,c). At these nitrate concentrations, $D_{w}$ dominated the total denitrification activity relative to $\mathrm{D}_{\mathrm{n}}$. Thus denitrifying activity was mainly enhanced close to the fish cages, where organic matter loading stimulated the process. DNRA was particularly stimulated immediately below the fish cages; DNRA activity was 4 - to 6-fold greater than denitrification activity, with rates of up to $7 \mathrm{mmol} \mathrm{N} \mathrm{m}^{-2} \mathrm{~d}^{-1}$ at a nitrate concentration of $13 \mu \mathrm{M}$. The latter reflected the autumn availability of nitrate in the system as the concentration increased from approximately $1 \mu \mathrm{M}$ in September to more than $20 \mu \mathrm{M}$ in November (Fig. 6). The measured rates of both $\mathrm{D}_{15}$ and DNRA of the added ${ }^{15} \mathrm{NO}_{3}{ }^{-}$may therefore reflect in situ activity in the fjord during fall and early winter. The present study thus confirms earlier observations that extremely high organic matter loading can reduce the importance of the denitrification process and stimulate nitrate reduction to ammonium (Kaspar et al. 1988, Gilbert et al. 1997). The DNRA rates reported here are high compared to other studies (Enoksson \& Samuelsson 1987, Binnerup et al. 1992, Sloth et al. 1995), and the process may therefore 
be of quantitative importance in sediment below the fish cages during periods of high water column nitrate concentrations.

\section{Relative importance of the processes}

Previously published models have predicted a positive correlation between sediment oxygen consumption and denitrification activity, thus enabling relatively simple estimation of nitrogen removal by denitrification (Christensen et al. 1990, Rysgaard et al. 1995, Seitzinger \& Giblin 1996). As demonstrated in the present study, however, denitrification was not stimulated even though oxygen consumption continuously increased under conditions of high organic matter loading below the fish cages (Figs, 2,6 \& 7a,c). That $D_{n}$ was the dominant denitrifying process during summer and DNRA was stimulated at increasing oxygen consumption rates has considerable bearing on predictions made using the above-mentioned models. The specific mechanisms regulating the processes under these conditions have yet to be elucidated, but the findings should be taken into account when applying the models under conditions of extreme organic matter loading.

Total denitrification in Horsens Fjord as a whole estimated from direct measurements was approximately $131 \mathrm{t} \mathrm{N}$ in 1996, corresponding to removal of $13 \%$ of the total annual $\mathrm{N}$ load from the land. It has previously been stated that denitrification in estuarine environments can generally remove $50 \%$ of the nitrogen load from the land (Seitzinger 1988). However, several studies demonstrate that denitrification rates are surprisingly similar in different estuaries and the denitrification rates reported here for the reference stations are thus of the same order of magnitude as those measured in other Danish and European estuaries (Christensen et al. 1994, Nielsen et al. 1994, 1995, Rysgaard et al. 1995, 1999, Dalsgaard et al. 2000). The percentage of nitrogen removed in different estuaries thus seems to depend more on variation in loading, depth, residence time, biological structure, etc. (Windolf et al. 1996, Christensen et al. 1998, Dalsgaard et al. 1999). For Danish estuaries, nitrogen removal by denitrification ranges from less than $2 \%$ of the nitrogen load from the land in highly flushed estuaries to almost $100 \%$ in estuaries with a high residence time and a low nitrogen load from the land (Nielsen et al. 1995, Rysgaard et al. 1995, Borum 1996). In this context, it is important to note that nitrogen input from adjacent marine waters may be an important nitrogen source in some estuaries. Consequently, it is not always relevant to relate denitrification rates solely to nitrogen loading from the land.

Integrated over the entire fish production season, denitrification activity below the fish cages was ap- proximately 2.5 -fold higher than that at the reference stations (Fig. 6). The additional organic matter load derived from fish production did not cause sufficient stimulation of denitrification activity to render nitrogen removal below the fish cages of any quantitative importance, though. During the 1996 production period, denitrification activity in the area covered by fish farms removed a total of $31 \mathrm{~kg} \mathrm{~N}$. Denitrification in the sediment immediately below the fish cages thus only removed $0.1 \%$ of the $25.7 \mathrm{t}$ nitrogen input to the fjord in connection with fish farming, and the additional $N$ and $\mathbf{P}$ was thus almost entirely available for primary production.

In contrast to denitrification activity, DNRA was stimulated below the fish cages. The few available studies of the quantitative importance of DNRA at fish production sites all confirm that this process is favored over denitrification in the heavily loaded sediments below the cages. The present study demonstrates that there is a high potential for DNRA, even at relatively low water column nitrate concentrations (Fig $7 \mathrm{c}$ ). The ecological consequence of this shift in the relative importance of the different processes as a result of increased organic matter loading is increased efflux of ammonium to the water column. This stimulates benthic and pelagic primary production and hence conserves excess nitrogen within the system. Aquaculture production has more than doubled during the last decade (FAO Fisheries Department 1997) and the environmental impact of such facilities can thus be expected to increase if the number of farms continues to rise on a global scale.

A direct relationship between nitrogen availability expressed as nitrogen concentration and primary production expressed as chlorophyll concentration has been found in temperate Danish coastal waters (Borum \& Sand-Jensen 1996, Christensen et al. 1998). Increased nitrogen loading from the land has resulted in massive phytoplankton production causing significant reductions in light penetration and the depth distribution of macrophytes in Danish coastal waters, as well as increasing episodes of oxygen depletion (Christensen et al. 1998). A major national action plan costing more than US $\$ 2.5$ billion has been implemented to reduce nitrogen and phosphorus loading of the aquatic environment by 50 and $80 \%$, respectively. In the light of this it seems highly relevant to critically evaluate the environmental impact of aquaculture production in shallow coastal waters. As demonstrated by the present study, $\mathrm{N}$ and $\mathrm{P}$ loading from the fish farms in Horsens Fjord, although covering less than $0.02 \%$ of its total area, corresponded to approximately 12 and $42 \%$, respectively, of total $\mathrm{N}$ and $\mathrm{P}$ loading from the land during the summer period. If only a minor fraction of the potential sites for fish production in Danish coastal 
waters are utilized, we will face severe problems due to direct input and changes in the benthic processes, where stimulation of nitrate reduction to ammonium will favor a retention and re-use of nitrogen within the system rather than removal of nitrogen through denitrification.

Acknowledgements. This study was financially supported by the European Union under the framework of MAST III (Marine Science and Technology III) and ELOISE (European Land-Ocean Interaction Studies) contract no. MAS3-CT960048, and by Vejle County Council, Denmark. This is ELOISE contribution no. 133.

\section{LITERATURE CITED}

Bédard C, Knowles R (1989) Physiology, biochemistry and specific inhibitors of $\mathrm{CH}_{4}, \mathrm{NH}_{4}^{*}$, and $\mathrm{CO}$ oxidation by methanotrophs and nitrifiers. Microbiol Rev 53:68-84

Binnerup SJ, Jensen $K$, Revsbech NP, Jensen MH, Sørensen J (1992) Denitrification, dissimilatory reduction of nitrate to ammonium and nitrification in a bioturbated estuarine sediment as measured with ${ }^{15} \mathrm{~N}$ and microsensor techniques. Appl Environ Microbiol 58:303-313

Borum J (1996) Shallow waters and land/sea boundaries. In: Jørgensen BB, Richardson K (eds) Eutrophication in coastal marine ecosystems. Coastal and Estuarine Studies, Vol 52. American Geophysical Union, Washington, DC, p 179-203

Borum J, Sand-Jensen K (1996) Is total primary production in shallow coastal marine waters stimulated by nitrogen loading? Oikos 76:406-410

Bower CE, Holm-Hansen T (1980) A salicylate-hypochlorite method for determining ammonia in seawater. Can J Fish Aquat Sci 37:794-798

Christensen PB, Nielsen LP, Sørensen J, Revsbech NP (1989) Microzonation of denitrification activity in stream sediments as studied with a combined oxygen and nitrous oxide microsensor. Appl Environ Microbiol 55:1234-1241

Christensen PB, Nielsen LP, Sørensen J, Revsbech NP (1990) Denitrification in nitrate-rich streams: diurnal and seasonal variation related to benthic oxygen metabolism. Limnol Oceanogr 3:640-651

Christensen PB, Mohlenberg F, Krause-Jensen D, Jensen HS, Rysgaard S, Clausen P, Sortkjær O, Schlüther L, Josefsen $\mathrm{SB}$, Jürgensen $\mathrm{C}$, Andersen $\mathrm{F} \varnothing$, Thomassen J, Thomsen MS, Nielsen LP (1994) Nutrient dynamic and transport in Kertinge Nor/Kerteminde Fjord (in Danish with English abstract). Havforskning fra Miljøstyrelsen, Vol 43. Danish Environmental Protection Agency, Copenhagen

Christensen PB, Møhlenberg F, Lund-Hansen LC, Borum J, Christiansen C, Larsen SE, Hansen ME, Andersen J, Kirkegaard J (1998) The Danish marine environment; has action improved its state? Havforskning fra Miljøstyrelsen, Vol 62. Danish Environmental Protection Agency, Copenhagen

Dalsgaard T, Bak F (1994) Nitrate reduction in a sulfatereducing bacterium, Desulfovibrio desulfuricans, isolated from rice paddy soil: sulfide inhibition, kinetics, and regulation. Appl Environ Microbiol 60:291-297

Dalsgaard T, Christensen PB, Rysgaard S, Risgaard-Petersen $N$ (2000) Nitrogen removal in Danish coastal waters: significance and regulation. In: Lomstein $B(e d)$ The marine environment in the year 2000 (in Danish). Danish Environmental Protection Agency, Copenhagen (in press)

Danish Environmental Protection Agency (1997) Aquatic environment 1997 (in Danish). Danish Environmental Protection Agency, Copenhagen

Enoksson V, Samuelsson MO (1987) Nitrification and dissimilatory ammonium production and their effects on nitrogen flux over the sediment-water interface in bioturbated coastal sediments. Mar Ecol Prog Ser 36:181-189

FAO Fisheries Department (1997) Aquaculture production statistics. FAO Fisheries Circular No. 815, Revision 9. FAO, Rome

Gilbert F, Souchu P, Bianchi M, Bonin P (1997) Influence of shellfish farming activities on nitrification, nitrate reduction to ammonium and denitrification at the water-sediment interface of the Thau Lagoon, France. Mar Ecol Prog Ser 151:143-153

Grasshoff K, Ehrhardt M, Kremling K (1983) Methods of seawater analysis. Verlag Chemie, Basel

Hall POJ, Holby O, Kollberg S, Samuelsson MO (1992) Chemical fluxes and mass balances in a marine fish cage farm. IV. Nitrogen. Mar Ecol Prog Ser 89:81-92

Hassager TK, Prince PS (1997) Plans for aquaculture in Denmark (in Danish). Danish Institute for Fisheries Research, Lyngby

Holmer M, Kristensen E (1994) Anaerobic mineralization of fish farm waste products in organic-rich sediments. In: Dyer KR, Orth RJ (eds) Changes in fluxes in estuaries. Olsen \& Olsen, p 283-289

Joye SB, Hollibaugh, JT (1995) Influence of sulfide inhibition of nitrification on nitrogen regeneration in sediments. Science 270:623-625

Karakassis I, Tsapakis M, Hatziyanni E (1998) Seasonal variability in sediment profiles beneath fish farm cages in the Mediterramean. Mar Ecol Prog Ser 162:243-252

Kaspar HF, Hall GH, Holland AJ (1988) Effects of sea cage salmon farming on sediment nitrification and dissimilatory nitrate reduction. Aquaculture 70:333-344

Nielsen K, Nielsen LP, Rasmussen P (1995) Estuarine nitrogen retention independently estimated by the denitrification rate and mass balance methods: a study of Norsminde Fjord, Denmark. Mar Ecol Prog Ser 119:275-283

Nielsen LP (1992) Denitrification in sediment determined from nitrogen isotope pairing. FEMS Microbiol Ecol 86 : $357-362$

Nielsen LP, Christensen PB, Revsbech NP, Sørensen J (1990a) Denitrification and photosynthesis in stream sediment studied with microsensor and whole-core techniques. Limnol Oceanogr 35:1135-1144

Nielsen LP, Christensen PB, Revsbech NP, Serensen J (1990b) Denitrification and oxygen respiration in biofilms studied with a microsensor for nitrous oxide and oxygen. Microb Ecol 19:63-72

Nielsen LP, Christensen PB, Rysgaard S (1994) Denitrification in estuaries and coastal waters (in Danish with English abstract). Havforskning fra Miljøstyrelsen, Vol 50. Danish Environmental Protection Agency, Copenhagen

Nishio T, Koike 1, Hattori A (1983) Estimates of denitrification and nitrification in coastal and estuarine sediments. Appl Environ Microbiol 45:444-450

Risgaard-Petersen N, Rysgaard S (1995) Nitrate reduction in sediments and waterlogged soil measured by ${ }^{15} \mathrm{~N}$ techniques. In: Alef $K$, Nannipieri $P$ (eds) Methods in applied soil and microbiology. Academic Press, London, p 287-310

Risgaard-Petersen N, Rysgaard S, Reusbech NP (1993) A sensitive assay for determination of ${ }^{14} \mathrm{~N} /{ }^{15} \mathrm{~N}$ isotope distribution in $\mathrm{NO}_{3}^{-}$. J Microbiol Methods 17:155-164

Risgaard-Petersen N, Rysgaard S, Revsbech NP (1995) Combined microdiffusion-hypobromite oxidation method for determining nitrogen-15 isotope in ammonium. Soil Sci 
Soc Am J 59:1077-1080

Risgaard-Petersen N, Dalsgaard T, Rysgaard S, Christensen PB, Borum J, McGlathery K, Nielsen LP (1998) Nitrogen balance of a temperate eelgrass Zostera marina bed. Mar Ecol Prog Ser 174:281-291

Rysgaard S, Risgaard-Petersen N, Nielsen LP, Revsbech NP (1993) Nitrification and denitrification in lake and estuarine sediments measured by the ${ }^{15} \mathrm{~N}$ dilution technique and isotope pairing. Appl Environ Microbiol 59:2093-2098

Rysgaard S, Christensen PB, Nielsen LP (1995) Seasonal variation in nitrification and denitrification in estuarine sediment colonized by benthic microalgae and bioturbating infauna. Mar Ecol Prog Ser 126:111-121

Rysgaard S, Thastum P, Dalsgaard T, Christensen PB, Sloth NP (1999) Effects of salinity on $\mathrm{NH}_{4}{ }^{+}$adsorption capacity, nitrification and denitrification in Danish estuarine sediments. Estuaries 22:21-30

Seitzinger SP (1988) Denitrification in freshwater and coastal undrine ecosystems. ecological and geochemical signifi cance. Limnol Oceanogr 33:702-724

Seitzinger SP, Giblin AE (1996) Estimating denitrification in

Editorial responsibility: Bess Ward,

Princeton, New Jersey, USA
North Atlantic continental shelf sediments. Biogeochemistry 35:235-260

Sloth NP, Blackburn H, Hansen LS, Risgaard-Petersen N Lomstein BA (1995) Nitrogen cycling in sediments with different organic loading. Mar Ecol Prog Ser 116:163-170

Sørensen J, Rasmussen LK, Koike I (1987) Micromolar sulfide concentrations alleviate acetylene blockage of nitrous oxide reduction by denitrifying Pseudomonas fluorescens. Can J Microbiol 33:1001-1005

Tiedje JM (1987) Ecology of denitrification and dissimilatory nitrate reduction to ammonium. In: Zehnder A.JB (ed) Biology of anaerobic microorganisms. Wiley, New York, p 179-244

Vejle County (1996) Survey of coastal waters 1995 (in Danish) Vejle County, Vejle

Vejle County (1997) Survey of point sources 1996 (in Danish). Vejle County, Vejle

Windolf J, Jeppesen E, Jensen JP, Kristensen P (1996) Modeling of seasonal variation in nitrogen retention and in-lake concentration: a four-year mass balance study in 16 shallow Danish lakes. Biogeochemistry 33:25-44

Submitted: March 12, 1999; Accepted: November 9, 1999 Proofs received from author(s): February 9, 2000 